\title{
Sister Local Tradition Existence In Rural Development: Sharing Space in Participative Development Planning in Neglasari Village
}

\author{
Utang Suwaryo ${ }^{1}$, Neneng Yani Yuningsih ${ }^{2}$, Iyep Saefulrahman ${ }^{3}$ \\ \{utang.suwaryo@unpad.ac.id $\left.{ }^{1}\right\}$ \\ Universitas Padjajaran ${ }^{1,2,3}$
}

\begin{abstract}
In rural development, community involvement is needed as community is the subject as well as object of the development. In its empirical level, in rural development planning, problems are often found related to the lack of community involvement. However, in Neglasari Village Salawu Sub-district Tasikmalaya Regency, the problems are not existed due to the existence of local tradition in the community life as well as in governance and development. The research aimed to analyze local tradition existence called babadamian in rural development planning in Neglasari. Therefore, the research used qualitative research approach with in-depth interview and documentation as data collection techniques. The research results indicate that babadamian played a strategic role in rural development planning as a channel for the community to convey their aspiration. Local elites became the determinant of the babadamian existence since it gave a balanced space to intensively plan rural development along with village deliberation meeting that formally set by the state to be conducted at village level.
\end{abstract}

Keywords: Local tradition, Development planning, Community participation

\section{Introduction}

Rural development is an integral part of national development and even one of its parameters. Due to the position, rural development plays an essential role since it is the determinant factor in the success and failure of national development as a whole. This Rural development as part of national and regional development is basically an overall effort in a series of planned activities carried out by the Government and the community, to improve the welfare of the community from various aspects of life, both economic, political, social and cultural [1].

In Indonesia context, rural development can be said as the spearhead of national development goals success to be achieved by the government. It is related to the history of the nation that builds by the people who are mostly live in the rural areas [2].

In its journey, rural development often faces with various classical problems. The problems are not only related to the financial aspect and its implementation but also in planning. Financing is a problem that most villages have to encounter since it is urgent to be handled. It could cause stagnation in rural development that consists of various programs; consequently, development goals are not achieved. To overcome it, although it could raise 
other problems such as village dependency to the state, the government issues various assistances both in form of direct program to be conducted by the villages (top down planning) and in form of grant to finance various rural development programs manage by the villages (bottom up planning).

Despite to the government assistance, rural development problems are not entirely solved. Another important problem unsolved is related to community involvement in the development. Referring to various policies issue by the government, community involvement effort has been conducted in every rural development program to be designed and implemented. In current context, village fund program opens an opportunity for all societies to involve not only in the utilization of successful program but also in the implementation, especially, in the development program planning. In reality, however, community involvement is relatively low in planning level as well as in the program implementation.

The condition cannot be separated from the initial policy of the government that uses top down approach in rural development planning. It limits and reduces community involvement in rural development. Another policy is related to the implementation of labor intensive program (Program Padat Karya)[3]. The program gives "daily wage" to the people involved in the development program implementation. Consequently, community involvement that was initially based on moral responsibility has shifted to material purposes. In the end, community involvement in the development depends on whether or not "wage" exists in the rural development program.

It is different to the condition in Neglasari Village, at least in terms of rural development program planning. Neglasari villagers mostly participate in rural development planning. A community that is active in rural development planning in the middle of community conditions that often do the opposite in most villages is an interesting matter. It is related to the community position itself that is not only an object but also to be expected as a subject in rural development. It is in the development program planning that both community positions are achieved. Certainly there must be something that becomes a determinant and makes Neglasari villagers to have such awareness to the village development, especially in the planning stage. This paper tries to explain condition built in Neglasari Village related to village fund policy.

\section{Method}

Law No. 6/2014 on Village mandates the importance of participation in rural development planning approach. In certain level, local wisdom-based development strategy in Neglasari Village is influenced by community participation in development planning and problem solving by using local potential and resources and maintaining local cultural values. Obstacles in local wisdom-based development strategies in Neglasari Village are insufficient communication and human resources. Based on the description, formulation of problems in the paper is how is the development planning in utilizing village fund in Neglasari Village Salawu Sub-district Tasikmalaya Regency?

\section{Result and Discussion}

The currently implemented village fund policy requires all villages, including Neglasari Village, to build their village intensely thus the fund is maximally absorbed. Rural development through village fund financing expects responsibility from all stakeholders in the 
village to build their village sustainably. The demand and expectation require an effective and efficient planning mechanism in utilizing the village fund. Small mistake in its utilization could have broad impact to the village governance, in general and in rural development, in particular.

Village fund-based development planning mechanism is actually similarto those conducted by other villages. Planning should refer to the state policy of Law No. 6/2014 on Village, the Village Minister's Regulation (Permendes) No.2/2015 on Village code of conduct and decision making mechanism, and Permendes No. 22/2016 on the Determination of Village Fund Utilization Priorities 2017 through an activity called village deliberation meeting. However, only BadanPermusywaratanDesa (village consultative body), village government, and village community elements take part in thedeliberation activity and it excludes the public. In participative development planning context, the mechanism would not be able to effectively absorb community aspiration as a whole. In addition, it is likely that the village community elements are actually part of the village government, such as head of RT (neighborhood association), head of RW (community unit), administrators of LPMD, PKK, KarangTaruna (youth association), village MUI, and etc. Empirically, it is those elements that mostly involve and being included in various development planning activities in the village.

For Neglasari Village, planning a rural development was not something new. Before the existence of various policies regulating the activity, as a legal community unit, Neglasari had its own mechanism manifested in a tradition. The tradition still existed and used for the village interest and its community interest. The tradition was called babadamian, which is a decision making mechanism inherited by the village elders [4].

Actually, babadamianwas identical to deliberation as commonly understood, which is a way or mechanism to make a decision and it is conducted by looking for mutual agreement to find consensus (musyawarah-mufakat). However, in state version deliberation (based on UU No. 6/2014, article 65, letter d), decision making is based on voting, which is each attended participants give their voice until it reaches the majority and it is possible if musyawarahmufakat (deliberation and consensus) is not achieved.

The mechanism was different to babadamian since the tradition did not prioritize the result but the process to exchange ideas and information for the development of Neglasari. In addition, babadamianwas not intended to look for justification on one village elder'(nongoverning elite) attitude and viewtoward other elders [5]. More important,babadamian was intended to maintain friendship (silaturahmi) among the elders of each kampung in Neglasari Village. This silaturahmiwas one of values that act as a bonding agent and reducer of human ego. Therefore, once again, the end result or decision taken in babadamianwas not the main thing since assessment on the decision result could be done once the decision implemented.

Another value was the belief that the result on decision taken either succeeded or failed, was not the babadamian's fault. There was a value followed by the community, especially the village figures, that it was the will of God. Human only acts and the end result will be in God's hand. In this case, it can be said that the failure for the implementation of resulted decision was not the end since errors could be repaired.

In its implementation, babadamian tended to be informal just like during deliberation community. There was no space and time limits for the village figures to implement it. Therefore, community involvement became wider in scope. It was not only involved the elites but, technically, it could be conducted everywhere. However, generally, it was often conducted at one of elite's home or at the mosque. In addition, due to the nature of the villagers, especially in Neglasari, that tends to give the best decision for the community in the 
hand of the public figures (elites), in certain matters babadamianwas conducted among the public figures only who were the non-governing elites or governing elites.

The elites' decisions were usually agreed by the villagers. There was a belief among the villagers that they who receive trust (generally the elders) could hold the mandate and make a decision for the general community interest instead of their own (the elites'). The belief was also the base for the birth of "local philosophies", among others: "kumaha nu dibendo" and "saurmanuk"within the villagers . "Kumaha nu dibendo"means that the society hands over all the decision to those who hold the power (authority) or position in the government, whereas saurmanuk means general agreement (acclamation) of the decision taken.

Another thing that differentiatesbabadamian to deliberation was when it was conducted between the village elites, space and time were adjusted to the existing condition and it did not have to be in a formal place, such as village hall (bale ) with fix working hour. Sometimes it conducted at the village head's house or punuh or head of RW or RT, or even at night (after isha' prayer) until midnight.

Meanwhile, regarding babadamian between village elites and the public, it was the elites that visited the villagers. Recitation activity conducted every week and month at the mosques that exists in every kampung is a tool to conduct babadamian. The purpose of babadamianwas more towards absorption of community's feedback regarding decision taken in babadamian between the elites in kampung and kapunuhan levels before it submitted to the village.

Up to now, the existence of babadamian tradition was still maintained and it worked effectively in Neglasari Village governance although it was informal and limited as a complement for village deliberation as stated by the state. However, referring to the Law No. 6/2014 on Village Article 80, the state requires community involvement in rural development planning. The law, indirectly, gives space and power to Neglasari Village to use its tradition (babadamian) in the formulation of rural development plan. Further study indicates that through babadamian, NeglasariVillage, had been implemented participative development planning theoretically and normatively as required by the state.

The work of babadamian in participative development planning in Neglasaricould be seen during the formulation of Village Medium Term Development Plan (Rencana Pembangunan Jangka Menengah Desa (RPJMDesa) and then outlines in Village Annual Development Plan or called Village Government Work Plan for 1 (one) year period. In the formulation of the two documents, babadamian played role as a bridge or connector between the village interest (one of them is representing the state interest) in one side and the interest and actual needs of the community on the other side.

One of village interests is when the village government set development priority scale to be funded by village fund. Based on the result of village deliberation in 2015, it was set that the development priorities are based on the history of kapunuhanestablishment. Therefore, the first priority will be Naga Kapunuhan and followed by Tanjaknangsi, Cikeusik, and Sukaratu. Meanwhile, Neglasari Village receives other assistances, such as assistance from the West Java Province. Therefore, the first turn is given to those that did not get a turn during the current year. During the deliberation for the development priority setting, all participants accepted the decision.

The agreement to receive deliberation result among the participants cannot be separated from babadamian conducted by the figures, both between the figures or between the figures and the community before the deliberation took place. Consideration taken by theelders regarding the decision was related to the existence of village tradition and the historical aspect of Neglasari Village, especially Kampung Naga in Kapunuhan Naga, which is the main kampung of all kampungsin Neglasari Village. 
Referring to the priority needs, there was a potential of conflict between kapunuhan and kampung. It can be said that, in general, every community wanted that development in their kapunuhan or kampung should be the priority. It was due to the consideration that it is urgent to handle development problems and there is uncertainty regarding the availability of grant for village development in the next year. However, through babadamian conducted either between the elites or between the elites and the communities in each kapunuhan and the strong community's belief to their leaders due to the existence of life philosopgy of kumaha nu dibendo, the possibility of conflict in village level during the village deliberation could be minimized.

Another decision was related to priority scale in the program and development activities for each kapunuhan. Another village deliberation decision was related to the determination of programs, activities, and needs for each kapunuhan. The result was agreed and it was fully handed over to the communities in each kapunuhan. In this case, it can be said that the determination of development program priorities in kapunuhan, the space, and power were held by the community with their tradition.

As previously explained the community's value and tradition of "kumaha nu dibendo" still worked and became the basis in the governance. As well as in the determination of program priorities and activities in kapunuhan and kampung, the community handed over the decision to their public figures. In addition, community knowledge and understanding was relatively low thus the public figures, who are considered to have superiority,were entrusted with mandate to decide. Therefore public figures in kapunuhan and kampung either governing elites (punuh, head of RW, RT, and several village institution administrators) or nongoverning elites (public figures in kapunuhan and kampung including the village figures) still played a significant role in the determination of program priorities and development activities in their kapunuhan and kampung.

With the local value that still worked, the determination of various development activities in each kapunuhanwas mostly conducted through babadamian between the elites of kapunuhan and kampung. Nevertheless, it did not mean that the community was not involved or participated in the planning of program priority determination and activities in their kapunuhan.

Due to the position, decisions taken in village deliberation, especially those related to rural development planning, did not come from the state's will.In addition, they were acceptable by the community indicated by their participation in the planning and implementation of rural development programs conducted at their kapunuhan and/orkampung. This is the real meaning of participative development planning.

The rules, indirectly, gave space and power to Neglasari Village to re-use their tradition (babadamian) in the formulation of rural development plan. As previously explained, babadamian is a decision making mechanism that looks for agreement as well as participation since its implementation requires community's active role. Babadamianwas not only conducted between the public figures but also between the public figures and the villagers of Neglasari, especially those who have power over themselves regarding the age and status. Therefore, decision making process in Neglasaricould be said as a participative decision making. 


\section{Conclusion}

Babadamian tradition that still exists in development planning in Neglasari Village could not be separated from the maintenance of local values thus it existed up to now. In this case, the village leaders (figures/elites) played a significant role since they were the one that make the local values were still believed and become the grip not only in the daily life but also in the village governance, especially in decision making.

In this rural government, babadamian became the "space" for the elites and Neglasari Village people to discuss the development program to be conducted at their village.

Desa(village) that initially as a legal community unit authorized in regulating and managing its own affairs with the friendly characteristic of its community becomes a kelurahan (village) as a working area of village head with its community that has patembayan character.

The function of babadamian for Neglasari village was to fill the empty space in absorbing community aspiration thus all community levels could participate in rural development planning. Thus the expectation of participative development planning realization could be achieved.

\section{References}

[1] F. Fitra, M. Madani, and M. Tahir, "Kepemimpinan Pemerintah Desa Dalam Percepatan Pembangunan Prasarana Wilayah Pemekaran Di Desa Lambanan Kecamatan Latimojong Kabupaten Luwu," Otoritas J. Ilmu Pemerintah., vol. 2, no. 1, 2012.

[2] T. Ardilah, "Upaya Kepala Desa untuk Meningkatkan Partisipasi Masyarakat dalam Pembangunan Desa (Studi di Desa Bareng Kecamatan Bareng Kabupaten Jombang)," J. Adm. Publik, vol. 2, no. 1, pp. 71-77, 2014.

[3] S. Bekun, A. J. A. Gani, and M. Makmur, "Strategi Pelaksanaan Program Padat Karya Pangan Dalam Meningkatkan Pemberdayaan Masyarakat Desa Di Kabupaten Timor Tengah Utara," WACANA, J. Sos. dan Hum., vol. 16, no. 2, pp. 65-70, 2013.

[4] et al. Saefulrahman, "The Invisible Power of Local Democracy in Neglasari," IJRSS June, vol. 5, no. 4, 2015.

[5] T. B. Bottomore, Elite dan Masyarakat. Jakarta: Akbar Tanjung Institute, 2006. 